\title{
Intangibles and methods for their valuation in financial terms: Literature review
}

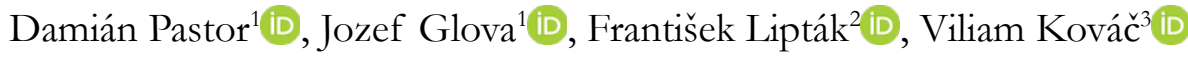 \\ ${ }^{1}$ Technical University of Košice, Faculty of Economics, Department of Banking and Investment (Slovakia) \\ ${ }^{2}$ Pavol Jozef Šafárike University in Košice, Faculty of Law, Department of Commercial and Business Law (Slovakia) \\ ${ }^{3}$ Technical University of Kosice, Faculty of Economics, Department of Finance (Slovakia) \\ damian.pastor@tuke.sk,,jozef.glova@tuke.sk,ferocius86@gmail.com,viliam.kovac@tuke.sk.
}

Received January, 2016

Accepted October, 2016

\section{Abstract}

Purpose: The purpose of this paper is to review literature devoted to intangibles and their valuation and give examples of the methods that can be used for valuation of individual intangibles in financial terms.

Design/methodology: The paper presents a systematic review of articles dedicated to intangibles and their valuation.

Findings: This article presents the definitions of intangibles, intangible assets, knowledge assets and other related terms. These terms are used interchangeably in spite of their different meanings. Differences and relations between these terms are clearly explained. The paper also proposes the list of basic intangibles with suggested methods for their valuation in financial terms. Income and cost approaches should be used mainly in this purpose. Market approach has only limited use. 
Research limitations/implications: Not all the papers related to this topic could be covered in this paper. Presented list of important intangible components may be enhanced and examples of some other methods for their valuation may be added in the future.

Practical implications: The paper calls for development of framework comprising list of the most important intangibles, proposals of methods used for their valuation and examples of their use. This framework can be helpful for organisation, which are confronted with a difficult task of intangibles valuation.

Originality/value: Basic definitions and differences between intangibles, intangible assets, identifiable intangible assets, knowledge assets and intellectual capital have not been mentioned in one paper yet. List of intangibles and methods for their valuation gives a direction for future work that can be fruitful for valuation of intangibles.

Keywords: Intangibles, Intangible assets, Intellectual capital, Knowledge, Valuations

Jel Codes: E22, O34

\section{Introduction}

By the end of the last century the economic literature has witnessed an increased interest in intangible assets, intellectual capital, knowledge assets, and other related terms. To date many articles, books and studies have been written on those terms. Some of them are mentioned throughout this article. These works, however, have not produced any consensus in many issues yet (Serenko \& Bontis, 2013). A similar situation is observable in the valuation of intangibles, which also received a considerable attention. None of the published methods has become a commonly used method worldwide (AlMusali \& Ismail, 2014). This paper is interested in the methods for valuation of individual intangible resources in financial terms. These methods are called financial valuation methods (Andriessen, 2004) or direct intellectual capital methods (Sveiby, 2010). Different categories of measurement approaches have different advantages, disadvantages, and are best suited for diverse measuring motives. According to Sveiby (2010), financial valuation methods are useful in merger \& acquisition situations, for estimates of the financial value of intangible assets and comparisons between companies within the same 
industry. Outputs of these methods can be used in accounting. Their disadvantage is that by translating everything into financial terms they can be superficial.

This paper aims to provide an overview of different views on intangibles and their valuation. The next section is devoted to intangible assets and related concepts that have been mentioned above. The definitions of these terms are presented and the differences between them are pointed out. This effort is in contrast to frequently used approach that considers all these terms as synonyms and mentions them interchangeably. However, in our opinion, this usual approach just contributes to chaos in this topic. In the third section the basic approaches used for valuation of intangibles in monetary terms are described shortly. After that the intangible assets, which we consider to be the most important for common company, are listed. Proposals of financial valuation methods are offered for each asset or group of assets.

\section{Basic Terms}

Intellectual capital, intangible assets, intangibles and knowledge assets can be labeled as related concepts. Many authors (Joia, 2000; Lev, 2000; Mayo, 2000; Bontis, 2001; Malhotra, 2000; Sánchez et al., 2001; Marr, Schiuma \& Neely, 2002; Lim \& Dallimore, 2004; O'Sullivan, 2009) use some of them interchangeably and do not distinguish between them. According to the Organisation for Economic Co-operation and Development (1999, pp. 17), the difference between intangible assets and intellectual capital exists: intangible assets are non-monetary assets without physical substance held for use in the production or supply of goods or services, for rental to others, or for administrative purposes and intellectual capital is the estimated, imputed economic value of intangible assets of a company. Petty and Guthrie (2000) claim that intellectual capital is often considered synonymous with intangible assets and the distinction between them has been vague. Lev (2000) uses the similar approach and points out that in various areas the preferred term differs - in accounting the intangible assets are popular, in the literature on human resources it is an intellectual capital, and the knowledge assets are mainly used by economists. Sánchez et al. (2001) in the final report of the project Meritum - Measuring intangibles to understand and improve innovation management - use the terms intellectual capital, intangibles and intangible assets interchangeably and consider them similar concepts with similar uses.

Next in this section, the view that all these terms can be used interchangeably is not supported. Some definitions of these terms together with the differences and relations between them are mentioned. At the end of the section, the relations between the components of intangibles are drawn in a figure. 


\subsection{Intangibles}

Probably the most common interchanged terms are intangibles and intangible assets. Cañibano, Covarsí and Sánchez (1999) claim that intangibles may be either assets or liabilities - intangible sources of expected economic benefits or losses. If authors do not deal with intangible liabilities, intangibles then agree with intangible assets. Sveiby (1998) cares just about intangible assets. According to him, the corresponding liability on the other side of the balance sheet is invisible equity, for instance the difference between market and book value of the company. If the positive difference between the market and the book value of the company is regarded as a consequence of the existence of the unrecorded intangible assets, then, as reported by Harvey and Lusch (1999), if there is a negative difference, the unrecorded intangible liabilities exist. Examples of intangible liabilities are weak strategic planning, unsafe working conditions, poor reputation of the firm and so on. Caddy (2000) distinguishes between intangible assets and liabilities too. Correspondingly to Harvey and Lusch (1999), Caddy (2000) argues that if there are intangible assets, from an accounting perspective they have to be balanced by intangible liabilities. Some other contributors to the concept of intangible liabilities can be found in the paper by Parra, Simo and Sallan (2006).

According to Caddy (2000), an intellectual capital is the difference between intangible assets and liabilities. However, the difference between intangible and intellectual exists and we get to it later in this paper. Therefore it is more precise to title the difference between intangible assets and liabilities as intangible capital. When drawing up the balance sheet, it is not sufficient to put intangible assets on the asset side and an adequate "invisible equity" on the other side. A correct way is to put intangibles assets on the left side and intangible liabilities on the right side and only their difference is reflected in the company's value and may be called "invisible equity" or "invisible liability" depending whether the difference is positive or negative.

\subsection{Knowledge assets and intangible assets}

Other terms which are often considered as synonyms are intellectual, knowledge and intangible assets. In the literature various definitions of these terms can be found - Kaufmann and Schneider (2004) and Choong (2008) mention some of them. International Accounting Standard 38 (International Accounting Standards Board, 1998) mentions as typical examples of intangible assets computer software, patents, copyrights, motion picture films, customer lists, mortgage servicing rights, fishing licenses, import quotas, franchises, customer or supplier relationships, customer loyalty, market share 
and marketing rights. But not all of these items meet the following International Accounting Standard 38 (International Accounting Standards Board, 1998) definition of intangible asset: "an intangible asset is an identifiable non-monetary asset without physical substance. An asset is a resource that is controlled by the entity as a result of past events and from which future economic benefits are expected to flow to the entity". Thus, International Accounting Standard 38 (International Accounting Standards Board, 1998) is interested only in identifiable intangible assets. Intangible assets in broader sense include also goodwill, which is non-identifiable intangible asset.

The three critical attributes of intangible assets covered by International Accounting Standard 38 (International Accounting Standards Board, 1998) are:

- identifiability;

- control;

- expected future economic benefits.

International Accounting Standards (International Accounting Standards Board,1998) are further devoted to these attributes that make a difference between identifiable intangible assets and unidentifiable goodwill. Goodwill is the subject of other standard International Financial Reporting Standard 3 created by the Business Combinations project. Identifiable intangible assets should be separable and arise from contractual or other legal rights. These requirements do not meet a lot of intangible resources which can bring to company future economic benefits and may have significant value.

Definitions of accounting standards focus on those intangible resources that can be identified, separated, and valued in the simplest way. This approach can be considered logical from an accounting perspective, but on the other hand, numbers of important intangible resources are simply regarded part of goodwill or they are accountably unrecognised. According to Córcoles (2010), the intangible assets can be grouped into visible and hidden, depending on whether they are accountably recognised. Within hidden intangible assets we can find internally generated unidentifiable intangible assets.

The fact that many intangible resources do not meet the conditions for intangible assets mentioned in accounting standards is noted also by Caddy (2000). He distinguishes between intangible assets and intellectual assets. Intellectual assets are hardly identifiable separately, determining their value is more difficult than for intangible assets and their value is also more volatile. Malhotra (2000) states that the worth of knowledge assets is hidden by current accounting and reporting practices. 
Up to now there is no established and universally accepted definition of knowledge assets. Boisot (1998, pp. 3) defines knowledge assets as "stocks of knowledge from which services are expected to flow for a period of time that may be hard to specify in advance". This definition clearly says that knowledge assets are just knowledge, not everything intangible. It means that knowledge assets are subset of intangible assets in the broad sense - intangible assets including identifiable and unidentifiable assets.

\subsection{Intellectual capital}

Many authors are interested in wider portfolio of intangible assets than those belonged to identifiable intangible assets in accordance with International Accounting Standard 38. These assets are then divided into different categories. Popular categorisations were proposed by Guilding and Pike (1990), Hendriksen and Van Breda (1992), Hammerer (1996), Mortensen, Eustace and Lannoo (1997), Werner, Hammerer and Schwarz (1998), and Young (1998). However, the most popular one is related to another term - intellectual capital.

Intellectual capital is usually divided into three components: human, structural, and relational or customer capital. Widespread is also the classification by Edvinsson and Malone (1997), where intellectual capital is divided in human and structural, and structural capital then consists of organisational and customer capital. Definitions of the components of intellectual capital are different. Some of them define parts of intellectual capital as set of knowledge (Petrash, 1996; Sánchez et al., 2001). But knowledge is not the single component of intellectual capital, although it is probably the most important one.

Becker (2011) states the human capital usually refers to employee capability, knowledge, innovation, adaptability, experience, and education. Relational capital includes relationships with customers and suppliers, company reputation, brand, distribution channels, and so on. Structural capital, according to Edvinsson and Malone (1997, pp. 11), is "everything left at the office when the employees go home", for instance databases, organisational structure, business processes and so on.

Not everything considered part of intellectual capital is knowledge. Therefore, there is a difference between knowledge and intellectual capital. Some authors do not share our views (Lev, 2000; Malhotra, 2000). Inconsistencies in this area often arise because of different opinions on what knowledge actually is. 
One of the best definitions of knowledge is concise definition of Turban and Frenzel (1992) which says "knowledge is information that has been organised and analysed to make it understandable and applicable to problem solving or decision-making”. As reported by Davenport and Prusak (1998), contrary to data and information, knowledge is closer to action. It is actionable information.

Knowledge is usually categorised as either tacit or explicit, although McInerney and Koenig (2011) present different, but very useful classification:

- explicit knowledge - knowledge in tangible form;

- implicit knowledge - knowledge in intangible form that could be transformed into tangible form if it is needed;

- tacit knowledge - knowledge in intangible form that one would have extreme difficulty operationally setting out in tangible form.

Based on the above definitions it can be concluded that implicit and tacit knowledge are important components of human capital and explicit knowledge is an important part of structural capital. Bontis (1999, pp. 444), using the term knowledge in a very broad sense, defines relational capital as "the knowledge embedded in the relationships established with the outside environment". However, in accordance with quite narrow definition of knowledge mentioned above, relational capital in general does not consist of knowledge. 


\subsection{Relations between components of intangibles}

Based on the above described differences and relations between the basic terms in the field of intangibles, the Figure 1 was created.

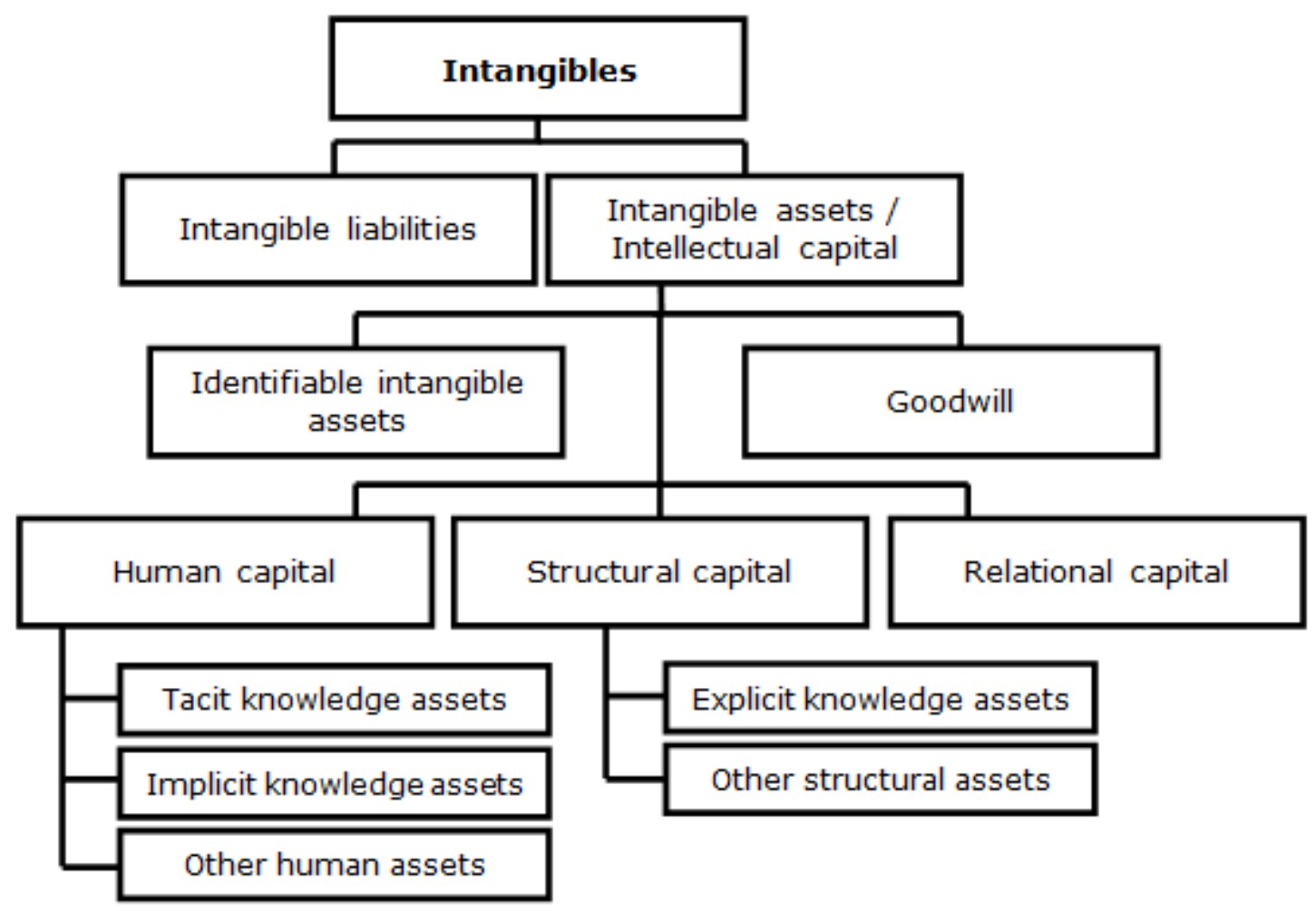

Figure 1. Relations between components of intangibles

Intangibles are composed of intangible assets and liabilities. Intangible assets and intellectual capital usually describe the same group of assets. In accordance with International Accounting Standard 38 (International Accounting Standards Board, 1998) intangible assets are divided into identifiable intangible assets and goodwill. Intellectual capital is typically divided into human, structural, and relational capital. Knowledge assets are subset of intangible assets and intellectual capital. Tacit and implicit knowledge assets are parts of human capital; explicit knowledge assets are components of structural capital. 


\section{Valuation of intangibles}

The valuation of intangibles is very complicated. This is despite the fact that there are many methods that have been proposed for that purpose. This paper is interested only in the methods dedicated to valuation of individual intangible resources - or small groups of intangibles - in financial terms.

Thornton (2013) lists three broad approaches for estimating fair values and the most used methods for financial valuation of intangible assets:

- market approach - the sales transactions comparison method, the market multiples method;

- income approach - the relief-from-royalty method, the comparative income differential method, the multi-period excess earnings method, the direct cash flow method;

- cost approach - the reproduction cost method, the replacement cost method.

Market methods are based on recent similar transactions and market prices of similar intangibles assets. These data are rarely available, so market approach has only limited use in practice.

The reproduction cost method estimates the costs incurred to reproduce the intangible asset in its acquisition date condition and the replacement cost method represents the costs to acquire a substitute asset of comparable utility today. Thornton (2013) states the cost approach is less widely accepted than market and income approach, especially because it ignores future economic benefits.

The relief-from-royalty method values the intangible asset by discounting royalty payments which the acquirer would have had to pay in an arm's length licensing arrangement to secure access to the same rights. The comparative income differential method (CIDM) estimates the value of the intangible assets as the difference between the value of the business with and without this asset. If reliable direct measurement of future economic benefits is not possible for some intangible assets, then the multiperiod excess earnings method (MEEM) can be used. This method starts with total expected income for a business or group of assets. After the charges for all the other assets are deducted, we get a residual income connected with intangible asset under valuation (Thornton, 2013). The direct cash flow method discounts expected cash flows coming from the intangible asset.

Lagrost, Martin, Dubois and Quazzotti (2010) propose more complex classification and listed some other methods used for valuation of intellectual property. 

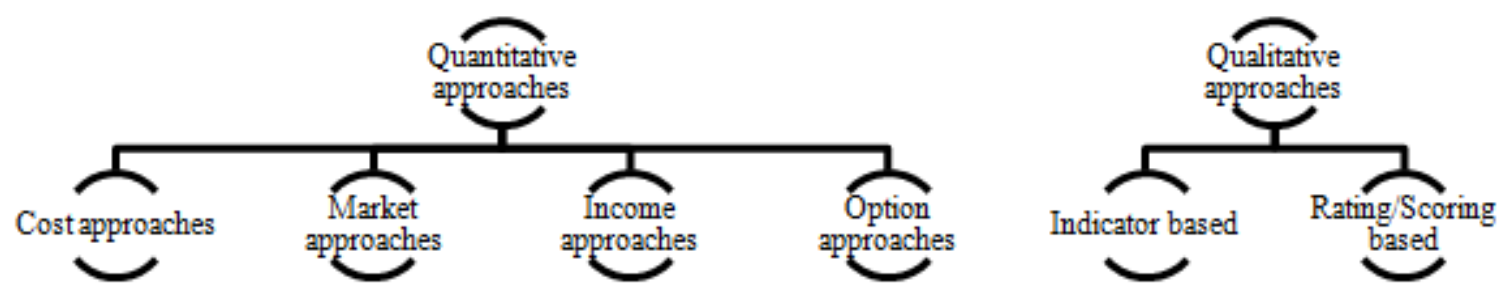

Figure 2. Major approaches for valuation of intangibles (Lagrost et al., 2010)

From quantitative approaches the group of option approaches has not been mentioned yet. It includes for example the real options method based on the Black-Scholes formula, the Monte Carlo method, and the binomial expansion based on decisional tree (Lagrost et al., 2010). There are also semiqualitative approaches for measuring intangibles assets. Verbano and Crema (2013) mention some articles adopting semi-qualitative method and propose an integrated framework for intangible capital measurement following a semi-qualitative approach.

Forty-two other methods for intangibles measurement are listed by Sveiby (2010), whilst thirteen of them are categorised as direct intellectual capital methods, which should estimate the monetary value of intangible assets by identifying its various components. Some of these methods are interested only in human capital - they are HRCA - Human Resource Costing and Accounting (Flamholtz, 1985; Johanson, 1996), HRS - Human Resource Statement (Ahonen, 1998), and Dynamic Monetary Model (Milost, 2007). Citation-Weighted Patents developed by Dow Chemical and described by Bontis (2001) are focused only on patents and intellectual property. Method of Sullivan (2000), IVM - Inclusive Valuation Methodology (M'Pherson \& Pike, 2001), and EVVICAE - Estimated Value Via Intellectual Capital Analysis (McCutcheon, 2008) do not evaluate individual intangible assets. The Value Explorer (Andriessen \& Tissen, 2000) and Total Value Creation are interested in core competencies and valuecreating activities respectively. Both methods propose use of discounting cash flow method (Stone \& Warsono, 2004). Discounted cash flow method is suggested also by Nash (1998) in his Accounting for the Future. Brooking (1996) recommends traditional approaches - cost, market, and income - for financial valuation of intangible assets. FiMIAM - Financial Method of Intangible Assets Measurement (Rodov \& Leliaert, 2002) calculates realised intellectual capital and based on top managers' suggestions divides this value between the most important components of intellectual capital. A big disadvantage of this relatively simple method is a high degree of subjectivity. All these thirteen methods can be useful, but they do not bring an important contribution to financial valuation of individual intangible assets. They have not replaced traditional methods which are still preferred in this field. 


\subsection{Valuation of identifiable intangible assets}

According to International Accounting Standard 38 (International Accounting Standards Board, 1998), an intangible asset shall be measured initially at cost. Cost of a separately acquired intangible asset comprises its purchase price and any directly attributable cost of preparing the asset for its intended use.

International Accounting Standards Board (1998) states that for intangible assets acquired in business acquisitions the cost is its fair value at the acquisition date. The most reliable estimate is quoted market price in an active market. But such a price is rarely available for intangible assets. Then the fair value can be estimated based on the price of recent similar transaction. If there is no active market for an intangible asset, fair value is the amount that the entity would have paid for the asset, at the acquisition date, in an arm's length transaction between knowledgeable and willing parties, on the basis of the best information available. In determining this amount, the outcome of recent similar transactions can be used and multiples may be applied.

Finally, according to International Accounting Standards Board (1998) the entity may estimate the fair value using techniques such as discounting estimated future net cash flows from the asset or estimating the costs that an entity avoids by owning the intangible asset and not needing:

- to license it from another party in an arm's length transaction;

- to recreate or replace it.

After the initial measurement, intangible assets are later valued by following models:

- cost model - initial cost less accumulated amortisation and impairment losses;

- revaluation model - revalued amount based on fair value less any subsequent amortisation and impairment losses - applied if fair value can be determined from an active (International Accounting Standards Board, 1998).

As mentioned earlier, goodwill is not considered as an identifiable intangible asset. It is measured as the difference between the market value of an entity and the carrying amount of its identifiable net assets at any time. Expenditure to acquire or generate non-identifiable intangible assets internally is recognised as an expense when it is incurred (International Accounting Standards Board, 1998). 


\subsection{Valuation of knowledge assets}

For valuation of knowledge assets it is important to identify organisation knowledge and knowledge of employees first.

\subsubsection{Tacit and implicit knowledge}

To evaluate the group of knowledge of the employee, it is necessary to separate knowledge from other parts of human capital. If we want to evaluate his/her particular knowledge, then we have to isolate this knowledge from his/her knowledge base. It means that value of tacit and implicit knowledge cannot be easily derived from wages, and it seems to be even more problematic to determine what increases in financial flows they will cause.

Possible options for their valuation are:

- cost approach - estimate how much it would cost to gain this knowledge;

- market approach and income approach - estimate a change in the employee's wage offered in the market due to the specific knowledge and calculate its current value - for instance what is the difference between the average salary offered for an economist with knowledge of English and German and for the economist only with knowledge of English; Saiz and Zoido (2005) estimate wage premium for college graduates who can speak a second language; based on this paper The Economist (2014) come with calculation of its value at retirement - it is a good example of this approach.

\subsubsection{Explicit knowledge}

Explicit knowledge includes all recorded and stored knowledge of an organisation.

Basic types of explicit knowledge are the following:

- intellectual property;

- other knowledge such as documented knowledge, product specifications, manuals, technical documentation, written processes and procedures, instructions, recipes, formulas, models, 
schematics, diagrams, designs, concepts, prototypes, algorithms, scripts, in-house developed software.

For intellectual property measurement the methods mentioned by Lagrost et al. (2010) can be used. Market and income approaches should be preferred.

Use of market approach for other knowledge assets is usually limited. If it is possible to reliably estimate cash flows caused by these intangible assets, then the income approach is a better choice than the cost approach.

Another way for measuring the knowledge assets, especially organisational processes, is knowledge value added analysis. It was proposed by Kanevsky and Housel (1998). It identifies the core processes of organisation and determines the knowledge required to execute each process.

Common measures used to estimate this amount of knowledge are:

- the time required to learn the process;

- the number of process instructions;

- the length of the sequence of binary questions - bits - required to complete the process (Marr, 2005).

Knowledge value added analysis assigns the revenues and costs to organisational processes and compare them in terms of relative productivity. According to Rodgers (2003) knowledge value added analysis methodology provides an objective measure of knowledge asset performance, but it falls short in capturing value for mergers, acquisitions, purchase or sale of separable assets, lawsuits involving intellectual property infringement, tax liability, and corporate alliances. This statement indicates that usage of knowledge value added analysis for valuation of all knowledge assets is unrealistic. On the other hand, this methodology seems to be an interesting way to measure and compare effectiveness of organisational processes. 


\subsection{Valuation of intellectual capital}

As it was already mentioned, intellectual capital has three basic components:

- human capital;

- $\quad$ structural capital;

- relational capital.

\subsubsection{Human capital}

For a valuation of human capital there are a wide range of methods. These methods are related to quite popular concept of HRA (Human Resource Accounting) or HRCA (Human Resource Costing and Accounting). Rao (2014) divides approaches to HRA into two groups: cost based and value based approaches. When talking about the most famous models of the valuation of human resources we have to mention the models of Lev and Schwartz (1971), Flamholtz (1971, 1972), Morse (1973), Jaggi and Lau (1974), Ogan (1976), Cascio (1996), Boudreau (1998), and Dobija (1998).

Lev and Schwartz (1971) propose following formula for calculating the value of individual employee:

$$
E\left(V_{\tau^{*}}\right)=\sum_{t=\tau}^{T} P_{\tau}(t+1) \sum_{i=\tau}^{t} \frac{I_{i^{*}}}{(1+r)^{t-\tau}}
$$

where:

$$
\begin{aligned}
& E\left(V_{\tau^{*}}\right) \text { - the human capital value of a person } \tau \text { years old; } \\
& P_{\tau}(t)-\text { probability of a person dying at age } t \\
& I_{i^{*}}-\text { estimates of the person's future annual earnings up to retirement; } \\
& r-\text { discount rate specific to the person; } \\
& t-\text { retirement age. }
\end{aligned}
$$

Lev and Schwartz (1971) assume that the employee will be working for the company until his death or until retirement. The possibilities of promotion, transfer to another position or leaving the organisation for other reasons than death or retirement were taken into account by Flamholtz $(1971,1972)$. 
Valuation of all employees on individual basis is very problematic for big organisations. Built on the models of Lev and Schwartz (1971) and Flamholtz (1971), Jaggi and Lau (1974) propose human resource valuation on a group basis. They claim that for the homogenous groups of employees it is easier to predict career movements and probability of leaving the company.

They calculate the expected economic value of employees as follows:

$$
[T V]=[N] \cdot \sum_{n=1}^{\infty} r^{n}[T]^{n}[V]
$$

where:

$[T V]$ - total expected economic value of employees;

$[T]^{n}$ - matrix of transitional probabilities aftern time periods;

$[N]-$ vector $\left[N_{1}, N_{2}, \ldots N_{k}\right], N_{i}$ being the number of employees in rank $i$ at time $t_{0}$;

$\left[\zeta-\right.$ vector $\left[V_{1}, V_{2}, \ldots V_{k}\right], V_{i}$ being the economic value of an employee of rank $i$;

$n$ - number of periods;

$r$ - discount rate;

$k-$ number of different ranks in the firm.

Mentioned models may be applied to estimate the value of individual employee or group of employees. Evaluation of individual parts of human capital is more challenging. The cost approach seems to be the easiest way to do it.

\subsubsection{Structural capital}

Knowledge falling under this category was already mentioned. Furthermore it comprises intangible assets to the four basic groups.

Organisational structure, corporate culture, rules, norms, and routines perform as the first group. These assets usually cannot be sold separately, but they may be acquired by franchising. Therefore their valuation can be based on expected cash flows from potential franchising. Of course, the value of 
some other intangible assets should be deducted from the value of franchising. To solve this problem the MEEM may be used. In many cases these intangibles have very low value for other organisations.

The second group is created by customer list, databases, and relevant information. If a duplicate is easily obtainable the fair value of customer list and similar databases is often estimated by cost approach. If these databases or information are not easily reproduced, or they represent a key advantage of the business, the income approach may be more appropriate (Thornton, 2013).

Website and domain name are involved in the third group. Value depends on usage. Thornton (2013) recommends income approach such as the relief-from-loyalty method if the domain names are frequently the subject of licensing arrangements and CIDM or MEEM if the business relies heavily on internet revenues. In other cases, especially when financial flows do not exist or their estimation is impossible, the value can be determined by cost approach.

Commercial software and information systems are the substance of the fourth group. Their valuation is usually based on market prices.

\subsubsection{Relational capital}

Relational capital consists of relations with customers, suppliers and partners, image, brand, reputation, customer loyalty and satisfaction, connections with suppliers, distribution channels, franchising and licensing agreements, etc.

Many of these intangible assets cannot be easily transferred from one entity to another, especially organisation relations with other parties. It is practically impossible to buy them. We can try to estimate their fair value through incremental financial flows or other income methods, but this task is very challenging. Therefore relational capital is usually measured by non-financial indicators. However, some methods used for valuation in financial terms exist.

Franchising and licensing agreements can be valued through discounting expected cash flows or relative valuation models (Damodaran, 2008).

For brand equity valuation, Salinas and Ambler (2009) present several models divided into three traditional groups on the cost, market and income methods. Salinas and Ambler (2009) cannot find current providers of cost methods and market methods have only limited use according to them. They 
compare income methods based on several criteria and list their advantages and disadvantages. Final choice of the method depends on the aim of valuation.

Valuation of reputation is easiest in its loss. After the scandal such as the Deepwater Horizon oil spill, the decline in the BP company's value largely corresponds to the loss of the reputation. Otherwise, it can be estimated from customer or market surveys. Customer surveys, market surveys, competitive analysis, and evaluation of ROI are methods suggested for measurement of some parts of relational capital by Brooking (1996).

Léger (2010) proposes the valuation of relational capital based on relational investments. Relational investments are investments to build and sustain network of suppliers and they include investments to finding competitive and innovative suppliers, establishing relationships, aligning business processes, training partners and, when necessary, managing conflicts and renewing agreements.

He calculates the value of relational capital as follows:

$$
U R C_{M V}=a+\theta\left(U R I_{t}\right)
$$

where:

$U R C_{M V}$ - market value of the upstream relationship capital;

$\theta$ - industry's average expected return on relational investments;

$U R I_{t}-$ total relational investments.

Abnormal return on relational investments can be achieved by the company. It is the difference between an individual performance and the average market performance (Léger, 2010).

\section{Conclusion}

A lot of papers were published about intangibles and their valuation. Nowadays it is needed to find the consensus between them. In this paper our view on intangibles and related terms is presented. Intangibles comprise intangible assets and intangible liabilities. International Accounting Standards are interested only in identifiable intangible assets which have to fulfil the requirements of identifiability, control, and existence of expected future economic benefits. Other intangible resources are part of goodwill. Knowledge assets are stock of knowledge, so they are a subset of intangible assets in the 
broad sense. More popular is concept of intellectual capital. It is composed of three parts: human, structural, and relational capital.

Valuation of intangibles is still a very complicated task, although many different methods have been already proposed. Basic methods for valuation of individual components of intangibles and intellectual capital in monetary units were mentioned in this paper. For valuation of identifiable intangible assets the market, income, cost, and option approaches are used. In the chapters dedicated to knowledge assets and intellectual capital, their basic components are listed with some methods suggested as applicable and appropriate for their valuation.

The interest of academics and practitioners should be given to valuation of intangibles liabilities, which are usually overlooked. However, they are important part of intangible statement in many cases. Volkswagen is a good current example of company with a bad reputation missing on the right side of its statement.

Widely accepted list of components of intangibles or intellectual capital with possible valuation methods and examples of their use would be very useful for organisations. The work presented by Thornton (2013) is a good illustration of this approach that should be followed and extended to whole intangibles.

\section{Acknowledgements}

This paper was created within the project supported by the Scientific Grant Agency of the Ministry of Education, Science, Research and Sport of the Slovak Republic 1/0922/15 Barriers and utilization possibilities of Pre-Commercial Procurement (PCP) approach in innovation public procurement in Slovak Republic. 


\section{References}

Ahonen, G. (1998). Henkilöstötilinpäätös: Yrityksen ikkuna menestykselliseen tulevaisunteen. Yrityksen Tietokirjat.

Al-Musali, M.A.K., \& Ismail, K.N.I.K. (2014). Intellectual capital and its effect on financial performance of banks: Evidence from Saudi Arabia. Procedia - Social and Behavioral Sciences, 164, 201-207. https://doi.org/10.1016/j.sbspro.2014.11.068

Andriessen, D. (2004). IC valuation and measurement: classifying the state of the art. Journal of intellectual capital, 5(2), 230-242. https://doi.org/10.1108/14691930410533669

Andriessen, D., \& Tissen, R. (2000). Weightless Wealtb: Finding your real value in a future of intangible assets. New York: Pearson Education.

Becker, G.S. (2011). The Oxford handbook of human capital. Oxford: Oxford University Press.

Boisot, M. (1998). Knowledge assets. Securing Competitive Advantage in the Information Economy. Oxford: Oxford University Press.

Bontis, N. (1999). Managing organisational knowledge by diagnosing intellectual capital: Framing and advancing the state of the field. International Journal of Technology Management, 18(5-8), 433-462. https://doi.org/10.1504/IJTM.1999.002780

Bontis, N. (2001). Assessing knowledge assets: A review of the models used to measure intellectual capital. International journal of management reviews, 3(1), 41-60. https://doi.org/10.1111/1468-2370.00053

Boudreau, J.W. (1998). Strategic human resource management measures: Key linkages and the peoplevantage model. Journal of Human Resource Costing \& Accounting, 3(2), 21-40. https://doi.org/10.1108/eb029046

Brooking, A. (1996). Intellectual Capital: Core Asset for the New Millenium Enterprise. London: International Thomson Business Press.

Caddy, I. (2000). Intellectual capital: Recognizing both assets and liabilities. Journal of Intellectual Capital, 1(2), 129-146. https://doi.org/10.1108/14691930010377469

Cañibano, L., Covarsí, M.G.A., \& Sánchez, M.P. (1999). The value relevance and managerial implications of intangibles: A literature review. In Measuring and reporting intellectual capital: Experiences, issues and prospects. Amsterdam: Organisation for Economic Co-operation and Development.

Cascio, W.F. (1996). The role of utility analysis in the strategic management of organizations. Journal of Human Resource Costing \& Accounting, 1(2), 85-95. https://doi.org/10.1108/eb029032 
Choong, K.K. (2008). Intellectual capital: definitions, categorization and reporting models. Journal of Intellectual Capital, 9(4), 609-638. https://doi.org/10.1108/14691930810913186

Córcoles, Y.R. (2010). Towards the convergence of accounting treatment for intangible assets. Intangible Capital, 6(2), 185-201.

Damodaran, A. (2008). Damodaran on valuation. Hoboken: John Wiley \& Sons.

Davenport, T.H., \& Prusak, L. (1998). Working knowledge: How organizations manage what they know. Boston: Harvard Business Press.

Dobija, M. (1998). How to place human resources into the balance sheet?. Journal of Human Resource Costing \& Accounting, 3(1), 83-92. https://doi.org/10.1108/eb029044

Edvinsson, L., \& Malone, M.S. (1997). Intellectual Capital: Realizing Your Company's True Value by Finding Its Hidden Brainpower. New York: Harper Business.

Flamholtz, E. (1971). A model for human resource valuation: A stochastic process with service rewards. Accounting Review, 46(2), 253-267.

Flamholtz, E. (1972). Toward a theory of human resource value in formal organizations. Accounting Review, 47(4), 666-678.

Flamholtz, E.G. (1985). Human Resource Accounting. San Francisco: Jossey-Bass.

Guilding, C., \& Pike, R. (1990). Intangible marketing assets: A managerial accounting perspective. Accounting and Business Research, 21(81), 41-49. https://doi.org/10.1080/00014788.1990.9729402

Hammerer, G. (1996). Intangible investments in Austria. In Workshop on New Indicators for the knowledge based economy. Paris: Organisation for Economic Co-operation and Development.

Harvey, M.G., \& Lusch, R.F. (1999). Balancing the intellectual capital books: Intangible liabilities. European Management Journal, 17(1), 85-92. https://doi.org/10.1016/S0263-2373(98)00065-6

Hendriksen, E.S., \& Van Breda, M.F. (1992). Accounting Theory (5th edition). Homewood: Irwin.

International Accounting Standards Board. (1998). International Accounting Standard 38: Intangible Assets. International Financial Reporting Standards. EC staff consolidated version as of 24 March 2010, International Accounting Standards Board, London.

Jaggi, B., \& Lau, H.S. (1974). Toward a model for human resource valuation. Accounting Review, 49(2), 321-329.

Johanson, U. (1996). Increasing the Transparency of Investments in Intangibles. Available online at: http://www.sveiby.com/articles/OECDartUlfjoh.htm 
Joia, L.A. (2000). Measuring intangible corporate assets: Linking business strategy with intellectual capital. Journal of Intellectual capital, 1(1), 68-84. https://doi.org/10.1108/14691930010371636

Kanevsky, V., \& Housel, T. (1998). The learning-knowledge-value cycle. In G. von Krogh, J. Roos \& D. Kleine, Knowing in firms: Understanding, managing and measuring knowledge (pp. 269-284). London: Sage Publications. https://doi.org/10.4135/9781446280256.n13

Kaufmann, L., \& Schneider, Y. (2004). Intangibles: A synthesis of current research. Journal of Intellectual Capital, 5(3), 366-388. https://doi.org/10.1108/14691930410550354

Lagrost, C., Martin, D., Dubois, C., \& Quazzotti, S. (2010). Intellectual property valuation: How to approach the selection of an appropriate valuation method. Journal of Intellectual Capital, 11(4), 481-503. https://doi.org/10.1108/14691931011085641

Léger, P.M. (2010). Interorganizational IT investments and the value upstream relational capital. Journal of Intellectual Capital, 11(3), 406-428. https://doi.org/10.1108/14691931011064617

Lev, B. (2000). Intangibles: Management, measurement, and reporting. Washington: Brookings Institution Press.

Lev, B., \& Schwartz, A. (1971). On the use of the economic concept of human capital in financial statements. Accounting Review, 46(1), 103-112.

Lim, L.L., \& Dallimore, P. (2004). Intellectual capital: management attitudes in service industries. Journal of Intellectual Capital, 5(1), 181-194. https://doi.org/10.1108/14691930410512996

M'Pherson, P.K. \& Pike, S. (2001). Accounting, empirical measurement and intellectual capital. Journal of Intellectual Capital, 2(3), 246-260. https://doi.org/10.1108/EUM0000000005659

Malhotra, Y. (2000). Knowledge assets in the global economy: Assessment of national intellectual capital. Journal of Global Information Management, 8(3), 5-15. https://doi.org/10.4018/jgim.2000070101

Marr, B. (2005). Management consulting practice on intellectual capital: Editorial and introduction to special issue. Journal of Intellectual Capital, 6(4), 469-473. https://doi.org/10.1108/14691930510630895

Marr, B., Schiuma, G., \& Neely, A. (2002). Assessing strategic knowledge assets in e-business. International Journal of Business Performance Management, 4(2-4), 279-295. https://doi.org/10.1504/IJBPM.2002.000119

Mayo, A. (2000). The role of employee development in the growth of intellectual capital. Personnel Review, 29(4), 521-533. https://doi.org/10.1108/00483480010296311

McCutcheon, G.A. (2008). EVVICA ${ }^{\mathrm{TM}}$, a valuation model for intellectual asset-rich businesses. Measuring business excellence, 12(2), 79-96. https://doi.org/10.1108/13683040810881216 
McInerney, C.R., \& Koenig, M.E. (2011). Knowledge management (KM) processes in organizations: Theoretical foundations and practice. Synthesis Lectures on Information Concepts, Retrieval, and Services, 3(1), 1-96. https://doi.org/10.2200/S00323ED1V01Y201012ICR018

Milost, F. (2007). A dynamic monetary model for evaluating employees. Journal of intellectual capital, 8(1), 124-138. https://doi.org/10.1108/14691930710715097

Morse, W.J. (1973). A note on the relationship between human assets and human capital. Accounting Review, 48(3), 589-593.

Mortensen, J., Eustace, C., \& Lannoo, K. (1997). Intangibles in the European economy. In Centre for European Policy Studies workshop on intangibles in the European economy. Brussels: Centre for European Policy Studies.

Nash, H. (1998). Accounting for the future, a disciplined approach to value-added accounting. Available online at: http://home.sprintmail.com/ humphreynash/overview.htm

Organisation for Economic Co-operation and Development (1999). Measuring and reporting intellectual capital: Experience, issues and prospects. Amsterdam: Organisation for Economic Co-operation and Development. Available online: http://www.oecd.org/sti/ind/2750309.pdf

Ogan, P. (1976). A human resource value model for professional service organizations. Accounting Review, 51(2), 306-320.

O'Sullivan, K. (2009). Strategic Intellectual Capital Management in Multinational Organizations: Sustainability and Successful Implications. Hershey: IGI Global.

Parra, M.G., Simo, P., \& Sallan, J.M. (2006). La evolución del capital intelectual y las nuevas corrientes. Intangible Capital, 2(13), 277-307.

Petrash, G. (1996). Dow's journey to a knowledge value management culture. European Management Journal, 14(4), 365-373. https://doi.org/10.1016/0263-2373(96)00023-0

Petty, R., \& Guthrie, J. (2000). Intellectual capital literature review: Measurement, reporting and management. Journal of Intellectual Capital, 1(2), 155-176. https://doi.org/10.1108/14691930010348731

Rao, A.L. (2014). Human Resource Accounting: A frame work for better Financial Accounting and Reporting. IOSR Journal of Business and Management, 16(4), 86-90. https://doi.org/10.9790/487X-16428690

Rodgers, W. (2003). Measurement and reporting of knowledge-based assets. Journal of Intellectual Capital, 4(2), 181-190. https://doi.org/10.1108/14691930310472802 
Rodov, I., \& Leliaert, P. (2002). FiMIAM: Financial method of intangible assets measurement. Journal of Intellectual Capital, 3(3), 323-336. https://doi.org/10.1108/14691930210435642

Saiz, A., \& Zoido, E. (2005). Listening to what the world says: Bilingualism and earnings in the United States. Review of Economics and Statistics, 87(3), 523-538. https://doi.org/10.1162/0034653054638256

Salinas, G., \& Ambler, T. (2009). A taxonomy of brand valuation practice: Methodologies and purposes. Journal of Brand Management, 17(1), 39-61. https://doi.org/10.1057/bm.2009.14

Sánchez, P. et al. (2001). Measuring Intangibles to Understand and Improve Innovation Management (MERITUM Final Report). European Commission, Brussels.

Serenko, A., \& Bontis, N. (2013). Investigating the current state and impact of the intellectual capital academic discipline. Journal of Intellectual Capital, 14(4), 476-500. https://doi.org/10.1108/JIC-11-2012-0099

Stone, D.N., \& Warsono, S. (2004). Does Accounting Account for Knowledge?. In Handbook on Knowledge Management 1 (pp. 253-269). Berlin: Springer Science+Business Media.

Sullivan, P. (2000). Value-Driven Intellectual Capital: How to Convert Intangible Corporate Assets into Market Value. Hoboken: John Wiley \& Sons.

Sveiby, K.E. (1998). Measuring Intangibles and Intellectual Capital - An Emerging First Standard. Available online at: http://www.sveiby.com/articles/EmergingStandard.html

Sveiby, K.E. (2010). Methods for Measuring Intangible Assets. Available online at: http://www.sveiby.com/articles/IntangibleMethods.htm

The Economist (2014). Johnson: What is a foreign language worth?. The Economist, 11th March 2014. Available online at: http://www.economist.com/blogs/prospero/2014/03/language-studv

Thornton, G. (2013). Intangible Assets in a Business Combination: Identifying and valuing intangibles under IFRS 3. Available online at: http://www.grantthornton.be/Resources/Intangible assets in a business combination Nov 2013.pdf

Turban, E., \& Frenzel, L.E. (1992). Expert systems and applied artificial intelligence. Upper Saddle River: Prentice Hall.

Verbano, C., \& Crema, M. (2013). Measuring IC following a semi-qualitative approach: An integrated framework. Intangible Capital, 9(3). 539-558. https://doi.org/10.3926/ic.427

Werner, C., Hammerer, G., \& Schwarz, K. (1998). Measuring intangible investment, intangible investment from an evolutionary perspective. In Measuring and reporting intellectual capital: Experiences, issues and prospects. Amsterdam: Organisation for Economic Co-operation and Development. 
Young, A. (1998). Towards an Interim Statistical Framework: Selecting the Core Components of Intangible Investment. Paris: Organisation for Economic Co-operation and Development. Available online at: http://www.oecd.org/sti/ind/1943301.pdf

Intangible Capital, 2017 (www.intangiblecapital.org)

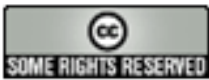

Article's contents are provided on an Attribution-Non Commercial 3.0 Creative commons license. Readers are allowed to copy, distribute and communicate article's contents, provided the author's and Intangible Capital's names are included. It must not be used for commercial purposes. To see the complete license contents, please visit http://creativecommons.org/licenses/by-nc/3.0/. 